\title{
Perspektywy terapii w polineuropatiach genetycznie uwarunkowanych
}

\section{Dagmara Kabzińska}

\section{Weronika Rzepnikowska}

\section{Katarzyna Binięda}

\section{Artur Kiepura}

\section{Andrzej Kochański ${ }^{\bowtie}$}

Zespół Nerwowo Mięśniowy, Instytut Medycyny Doświadczalnej i Klinicznej im. Mirosława Mossakowskiego Polskiej Akademii Nauk, Warszawa

Zespół Nerwowo Mięśniowy, Instytut Medycyny Doświadczalnej i Klinicznej im. Mirosława Mossakowskiego Polskiej Akademii Nauk, ul. Pawińskiego 5, 02-106 Warszawa; tel.: (22) 6086 536, e-mail: akochanski@imdik. pan.pl

Artykuł otrzymano 21 maja 2018 r.

Artykuł zaakceptowano 19 lipca 2018 r.

Słowa kluczowe: Choroba CMT, patogeneza molekularna, terapia eksperymentalna

Wykaz skrótów: AAV - wirusy towarzyszące adenowirusom (wektory oparte na tych wirusach); Ad - adenowirus (wektor adenowirusowy); AC (ang. adenylyl cyclase) - cyklaza adenylanowa; CMAP (ang. compound muscle action potential) - złożony potencjał ruchowy; wynik badania elektroneurograficznego, będący sumą potencjałów czynnościowych z wszystkich pobudzanych włókien mięśniowych; CMT - choroby kręgu Charcot-Marie-Tooth; HSV - wirus opryszczki (wektor oparty na wirusie opryszczki); LV - Lentiwirus (wektor Lentivirusowy); SMARD1 (ang. spinal muscular atrophy with respiratory distress type 1) - przeponowa postać rdzeniowego zaniku mięśni; UPR (ang. unfolded protein response) - odpowiedź komórki na nieprawidłowo zwinięte białka

Podziękowania: Badania prowadzone przez autorów niniejszej pracy przeglądowej są finansowane ze środków na naukę przyznanych przez Narodowe Centrum Nauki na realizację projektu UMO-2016/23/B/NZ3/02035 oraz przez Instytut Medycyny Doświadczalnej i Klinicznej im. Mossakowskiego.

\section{STRESZCZENIE}

$\mathbf{P}^{\mathrm{s}}$ olineuropatie genetycznie uwarunkowane (HMSN, ang. hereditary motor and sensory neuropathies) zwane również chorobami kręgu Charcot-Marie-Tooth (CMT) stanowią niezwykle heterogenną genetycznie (ponad 80 genów) grupę chorób obwodowego układu nerwowego człowieka. Istotą chorób kręgu CMT jest powolnie postępujący zanik mięśni dystalnych kończyn dolnych (podudzia) i górnych (przedramiona). Jak dotąd nie opracowano skutecznej metody leczenia CMT. W pracy przedstawiono obecny stan wiedzy dotyczący kliniki, patogenezy molekularnej i pierwszych prób terapeutycznych w CMT. Omówiono również możliwości wynikające $\mathrm{z}$ zastosowania modelu drożdżowego $\mathrm{w}$ poszukiwaniach nowych substancji leczniczych, jak i identyfikacji substancji neurotoksycznych.

\section{WPROWADZENIE}

Polineuropatie uwarunkowane genetycznie (HMSN, ang. hereditary motor and sensory neuropathies) zwane również chorobami kręgu Charcot-Marie-Tooth (CMT) występują z częstością ok. 1:2 500 osób [1]. Warto jednak zaznaczyć, że występowanie CMT w poszczególnych krajach jest bardzo nierównomierne, np. w Serbii choruje zaledwie ok. 10 osób na 100 tys. mieszkańców, we Włoszech i w Wielkiej Brytanii około 18 osób na 100 tysięcy mieszkańców, natomiast w Norwegii aż 82 osoby [2]. Przyjmując średnią częstość występowania CMT (1:2500 osób) w Polsce należy spodziewać się liczby około 15000 chorych. Choroby kręgu CMT dziedziczą się w sposób autosomalny dominujący, autosomalny recesywny, sprzężony z płcią dominujący oraz sprzężony z płcią recesywny.

Mimo dość dużego zróżnicowania fenotypów, cechą wspólną dla wszystkich postaci CMT jest powoli postępujące osłabienie i zanik mięśni dystalnych kończyn (podudzia, przedramiona). Istnienie innych składowych zespołu CMT (zaburzenia czucia, zaburzenia funkcji układu autonomicznego, skrzywienie kręgosłupa, drżenie rąk, etc.) zależy od typu (ponad 100 typów) choroby. W najczęściej występującej odmianie, CMT1A, już w pierwszej dekadzie życia obserwuje się zniekształcenie stóp i zaburzenie chodu. Początkowo niedowład i zanik mięśni obejmuje mięśnie dystalne kończyn dolnych, a następnie kończyn górnych. Z upływem czasu niedowład mięśni może poszerzyć się o mięśnie ksobne kończyn dolnych (uda). W przypadku postaci CMT o dziedziczeniu recesywnym przebieg kliniczny jest znacznie cięższy i u niektórych chorych prowadzi do inwalidztwa (unieruchomienie na wózku). W niektórych przypadkach CMT dochodzi do znacznego upośledzenia czucia, które niekiedy prowadzi do powstania owrzodzeń w obrębie rąk i stóp oraz do amputacji [3].

\section{HETEROGENNOŚĆ GENETYCZNA CHORÓB KRĘGU CHARCOT-MARIE-TOOTH}

Pomimo pozornie jednolitego obrazu klinicznego chorób kręgu CMT, polineuropatie genetycznie uwarunkowane charakteryzują się znaczną heterogennością genetyczną. Jak dotąd zidentyfikowano ponad 1000 mutacji w ponad 80 genach [4], kodujących białka reprezentujące szerokie spektrum występowania, pełnionych funkcji i charakterystyki biochemicznej (Ryc. 1). Pomimo dynamicznego rozwoju nowych technik sekwencjonowania (tzw. sekwencjonowanie nowej generacji), szacuje się, że około 18\%-50\% chorych wciąż pozostaje bez diagnozy molekularnej [5,6]. Przyczyn tego zjawiska może być kilka. Po pierwsze, występowanie rearanżacji genomowych, które mogą powodować chorobę poprzez kilka mechanizmów obejmujących m.in. zaburzenie struktury chromatyny (efekt pozycji), zmianę ekspresji genów poprzez zmianę liczby alleli, czy zjawisko odsłonięcia (ang. unmasking) alleli recesywnych [7]. Po drugie, pojawienie się zmian w niekodującym RNA czy w niekodujących częściach genomu, które są bardzo rzadko przedmiotem badań genetycznych. 


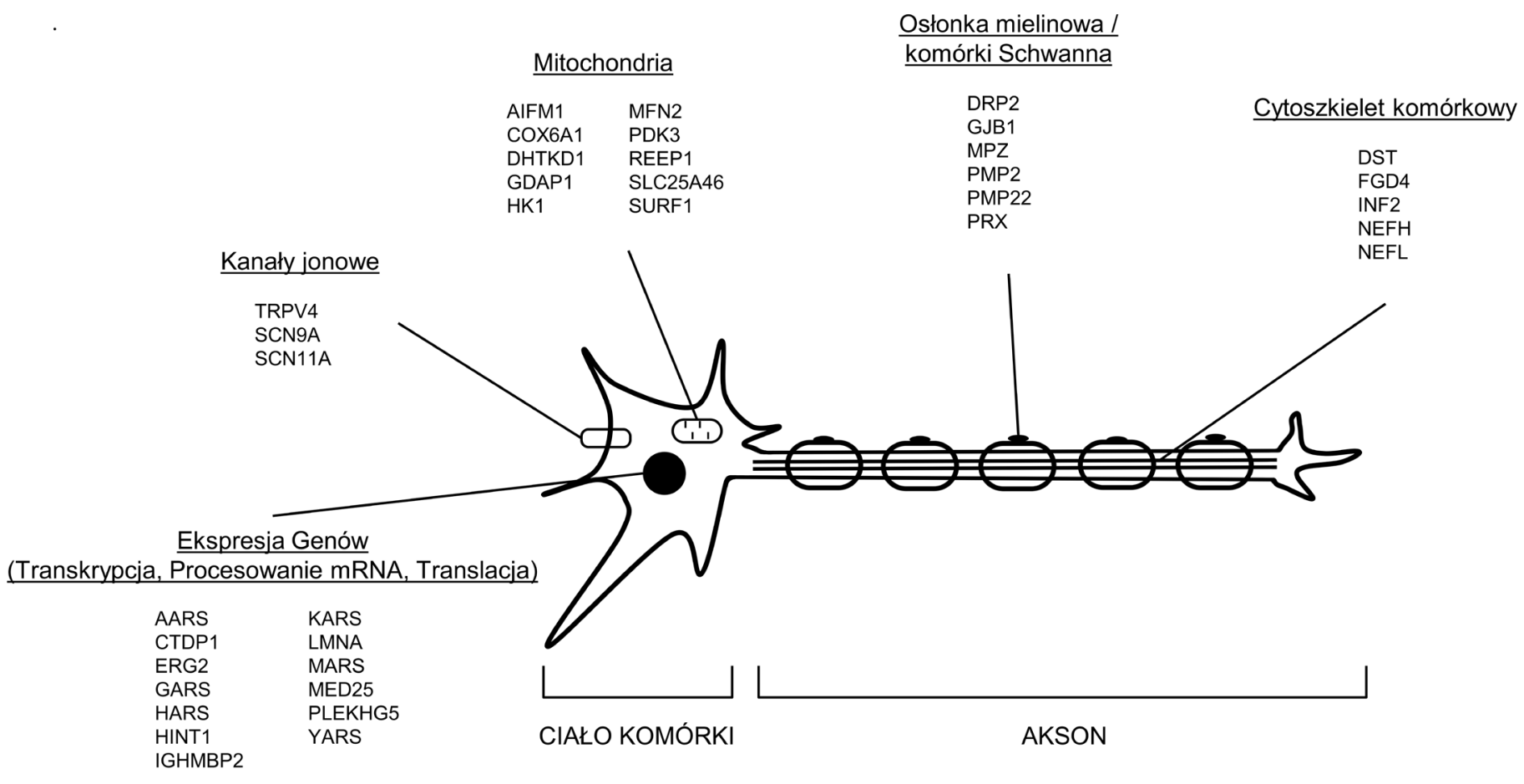

Transport wewnatrzkomórkowy

$\begin{array}{lll}\text { DCTN1 } & \text { KIF1B } & \text { RAB7 } \\ \text { DNM2 } & \text { KIF5A } & \text { SBF1 } \\ \text { DYNC1H1 } & \text { LITAF } & \text { SBF2 } \\ \text { FIG4 } & \text { MTMR2 } & \text { SH3TC2 } \\ \text { KIF1A } & \text { MYH14 } & \text { SPG11 }\end{array}$

Homeostaza białek

CCT5 HSPB3

DCAF8 HSPB8

DNAJB2 MME

HSPB1 TRIM2 $\underline{\text { Transdukcja sygnału }}$

GNB4

LRSAM1

NGF-B

NTRK1

SPTLC1

SPTLC2

WNK1

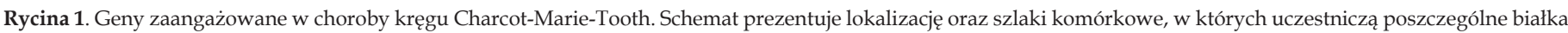
kodowane przez geny związane $\mathrm{z}$ wystąpieniem choroby.

Nie można również wykluczyć, że niektóre z polineuropatii uwarunkowane są w sposób wielogenowy, to znaczy, że za ich wystąpienie odpowiada kilka mutacji zlokalizowanych w różnych genach.

W klasyfikacji CMT wyróżnia się dwie podstawowe grupy: polineuropatię demielinizacyjną związaną z występowaniem nieprawidłowości $\mathrm{w}$ osłonce mielinowej, charakteryzującą się obniżoną szybkością przewodzenia $\mathrm{w}$ nerwach, oraz postać aksonalną, objawiającą się głównie degeneracją aksonów komórek nerwowych bez wyraźnych oznak demielinizacji [8]. Jako kryterium podziału przyjmuje się szybkość przewodzenia $38 \mathrm{~m} / \mathrm{s}$ we włóknach ruchowych nerwu pośrodkowego. Dalszego podziału na poszczególne typy dokonuje się uwzględniając rodzaj dziedziczenia i podłoże genetyczne. Najczęściej występujące neuropatie należą do grupy demielinizacyjnej i są związane $\mathrm{z}$ mutacjami $\mathrm{w}$ trzech genach: PMP22, GJB1 oraz MPZ [9]. Z kolei polineuropatie aksonalne są wysoce heterogenne pod względem genetycznym. Najczęściej zmutowanym genem jest MNF2, kodujący mitofuzynę 2 stanowiący (w niektórych populacjach) nawet do $20 \%$ wszystkich przypadków tego typu neuropatii [10]. Poniżej pokrótce zostaną omówione najważniejsze geny, w których mutacje powodują wystąpienie poszczególnych fenotypów.

\section{CHOROBA CHARCOT-MARIE-TOOTH TYPU DEMIELINIZACYJNEGO}

Najczęściej występującym typem choroby CMT, jest polineuropatia demielinizacyjna CMT1A, stanowiąca ok 40$60 \%$ wszystkich przypadków choroby CMT $[9,10]$. Na ogół objawia się ona $\mathrm{w}$ pierwszej lub drugiej dekadzie życia i charakteryzującej się zwykle łagodnym lub umiarkowanym przebiegiem. Choroba CMT1A u większości chorych wywołana jest duplikacją genu PMP22 (ang. Peripheral Myelin Protein 22) [11]. Białko PMP22 bierze udział w tworzeniu, uszczelnianiu i stabilizacji osłonki mielinowej oraz różnicowaniu komórek Schwanna [12-14]. Z kolei delecja genu PMP22 prowadzi do dziedzicznej neuropatii z nadwrażliwością na ucisk (HNPP, ang. hereditary neuropathy with liability to pressure palsies), która zwykle jest łagodnym schorzeniem charakteryzującym się epizodycznymi niedowładami mięśni dystalnych kończyn dolnych i górnych [15].

Drugim najczęstszym typem CMT (około 10\% wszystkich pacjentów) jest choroba CMTX1 (znana również jako CMT1X), wywołana mutacjami genu GJB1 (ang. Gap-Junction Beta 1), który koduje koneksynę-32 (ang. connexin-32; Cx32) $[9,16]$. Choroba CMTX1 jest sprzężona z płcią i dziedziczy się dominująco, jednak mężczyźni chorują ciężej niż kobiety. Co ciekawe, $\mathrm{w}$ przypadku tego typu CMT patologia 
aksonów jest bardziej widoczna niż w przypadku innych neuropatii demielinizacyjnych, co może sugerować pierwotne ich uszkodzenie [17]. Koneksyna-32 odgrywa rolę w komunikacji komórkowej poprzez tworzenie tzw. połączeń szczelinowych (ang. gap junction) [18,19]. Są to kompleksy białkowe tworzące kanały, które łączą cytoplazmę sąsiednich komórek i umożliwiają międzykomórkową wymianę jonów, drobnocząsteczkowych metabolitów, czy cząsteczek sygnałowych. W nerwach obwodowych koneksyna-32 znajduje się tylko w niektórych rejonach mieliny [20,21], gdzie prawdopodobnie tworzy połączenia szczelinowe pomiędzy poszczególnymi warstwami osłonki mielinowej [20].

Mutacje w genie MPZ (ang. Mielin Protein Zero), kodującym, podobnie jak PMP22, białko mieliny, stanowią ok. 3-5\% wszystkich przypadków CMT [9] i prowadzą do typu choroby CMT1B dziedziczonej autosomalnie dominująco [22]. Choroba CMT1B charakteryzuje się na ogół wcześniejszym początkiem i cięższym przebiegiem klinicznym niż CMT1A. Białko MPZ jest produkowane tylko w komórkach Schwanna wytwarzających mielinę (ang. myelinating Schwann cells) [23]. Stanowi ono aż 50\% wszystkich białek mieliny i odpowiada za spójność osłonki mielinowej [24,25]. Pokazano, że patogenny mechanizm wielu mutacji w genie $M P Z$ polega na zaburzeniu transportu zmienionego białka MPZ na powierzchnię komórki i zatrzymaniu go w siateczce śródplazmatycznej (ER). Prowadzi to do indukowania odpowiedzi komórki na nieprawidłowo zwinięte białka (UPR, ang. unfolded protein response), objawiającej się zwiększeniem produkcji białek odpowiedzialnych za przywrócenie homeostazy białkowej oraz zmniejszeniem syntezy i wzrostem degradacji pozostałych białek, a w skrajnych przypadkach prowadzącej nawet do apoptozy [26,11].

\section{CHOROBA CHARCOT-MARIE-TOOTH TYPU AKSONALNEGO}

Jak wspomniano wyżej najczęstszą przyczyną CMT typu aksonalnego są mutacje w genie MFN2, kodującym mitofuzynę 2. W większości przypadków mutacje genu MFN2 dziedziczone są autosomalnie dominująco i prowadzą do wystąpienia choroby CMT2A [27]. Choroba objawia się nie tylko neuropatią, ale często prowadzi do nieznacznego uszkodzenia ośrodkowego układu nerwowego [28,29]. Mitofuzyna 2 jest bardzo szeroko rozpowszechnioną, podobną do dynaminy GTPazą, zlokalizowaną w zewnętrznej błonie mitochondrialnej. Najbardziej znaną jej funkcją jest udział w fuzji zewnętrznej błony mitochondrialnej, aczkolwiek bierze ona także udział $w$ transporcie oraz degradacji mitochondriów [30-33]. Nic więc dziwnego, że wskazuje się na kilka mechanizmów, które mogą prowadzić do pojawienia się objawów polineuropatii. Należą do nich: zaburzenia równowagi pomiędzy fuzją i podziałem sieci mitochondrialnej, zmiany w transporcie i dystrybucji mitochondriów w komórkach nerwowych, upośledzenie degradacji mitochondriów na drodze autofagii (mitofagii) czy cytotoksyczność wywołana upośledzeniem funkcjonowania mitochondriów [31,29].

Innymi szeroko rozpowszechnionymi w tkankach genami zaangażowanymi w neuropatie są geny kodujące syntetazy aminoacylo tRNA (geny $A R S$ ). Do tej pory zidentyfikowano sześć genów $A R S$, w których mutacje prowadzą do wystąpienia CMT: GARS, YARS, AARS, KARS, HARS oraz MARS [34-39]. Kodują one odpowiednio syntetazy glicylo-, tyrozylo-, alanylo-, lizylo-, histydylo-, oraz metionino-tRNA. Co ciekawe, podczas gdy mutacje heterozygotyczne w genach ARS są zwykle związane z aksonalnym typem CMT, homozygotyczne mutacje w tych genach prowadzą zazwyczaj do poważnych zespołów, często z udziałem wielu narządów [40]. Syntetazy aminoacylo-tRNA są enzymami, które przeprowadzają reakcję przyłączenia odpowiedniego aminokwasu do cząsteczki tRNA, a tym samym są niezbędne do procesu translacji. Od dawna zastanawiano się dlaczego zmiany $\mathrm{w}$ tych szeroko rozpowszechnionych, kluczowych białkach prowadzą do wybiórczej degeneracji aksonów. Na przestrzeni lat pojawiło się wiele hipotez, w tym utrata aktywności enzymatycznej, zmiana lokalizacji w komórce oraz przyłączanie niewłaściwych aminokwasów do danego tRNA. Jednakże w świetle obecnej wiedzy żadna z nich nie wydaje się być prawdziwa. Obecnie uważa się, że przyczyną choroby może być nabycie nowej funkcji przez wymienione enzymy, która jest niezależna od aktywności katalitycznej oraz prowadzi do spowolnienia translacji $[41,40]$. Mutacje w genie GARS zmieniają konformację kodowanej przez ten gen syntetazy glicylo-tRNA. Nabywa ona nowych właściwości do wiązania receptora dla neuropiliny 1 (Nrp1), która w prawidłowych warunkach powinna oddziaływać z czynnikiem wzrostu śródbłonka naczyniowego (VEGF). Obniżenie ekspresji Nrp1 u myszy prowadziło do zaostrzenia objawów CMT, podczas gdy zwiększenie ekspresji VEGF poprawiało funkcje motoryczne [42].

Dziedziczne neuropatie aksonalne są też spowodowane mutacjami w genach kodujących małe białka szoku cieplnego (sHsp, ang. small heat shock proteins;). W genomie ludzi występuje 10 takich genów - HSPB1-10 [43]. Do tej pory udowodniono, że mutacje w trzech genach HSPB: HSPB1, HSPB3 oraz HSPB8 prowadzą do CMT, jak również do dziedzicznych neuropatii ruchowych [44-46], z czego najwięcej mutacji jak dotąd opisano w HSPB1 [http://www.hgmd. cf.ac.uk/ac/index.php], kodującym HspB1, zwane również Hsp27 lub Hsp28. HspB1 jest szeroko rozpowszechnionym, niezależnym od ATP białkiem opiekuńczym (z ang. chaperone - opiekun) zaangażowanym, podobnie jak inne białka szoku cieplnego, w kontrolę jakości białek [47]. Jego główną rolą jest wychwytywanie i zabezpieczanie przed agregacją nieprawidłowo sfałdowanych polipeptydów i kierowanie ich do ponownego zwijania lub degradacji. HspB1 jest również zaangażowany w kontrolę organizacji cytoszkieletu komórkowego oraz posiada właściwości antyapoptotyczne i antyoksydacyjne [48]. W zależności od mutacji zmodyfikowane białko charakteryzuje się zmienionymi zdolnościami do tworzenia oligomerów, zmniejszeniem lub zwiększeniem aktywności jako białka opiekuńczego lub zmianą $\mathrm{w}$ oddziaływaniu z partnerami białkowymi oraz docelowymi białkami (np. tubuliną) [49].

Na szczególną uwagę wśród genów związanych z CMT, zasługuje gen GDAP1 (ang. Ganglioside Induced Differentiation Associated Protein 1). Osobliwością mutacji występujących $\mathrm{w}$ tym genie są możliwe dwa sposoby dziedziczenia (recesywnie i dominująco) oraz szerokie spektrum fenotypowe choroby: od bardzo łagodnej, gdzie niewielkie nieprawidłowości obserwowane są właściwie tylko w obrazie 
elektromiograficznym, do ciężkiej formy o wczesnym początku i szybkim przebiegu prowadzące do niepełnosprawności [50]. Białko GDAP1 produkowane jest głównie w komórkach nerwowych, gdzie lokalizuje się w zewnętrznej błonie mitochondrialnej oraz w peroksysomach [51-53]. Jego funkcja molekularna nie jest wyraźnie sprecyzowana. Wykazano, że białko to uczestniczy w wielu kluczowych procesach komórkowych, takich jak: podział sieci mitochondrialnej, transport i lokalizacja mitochondriów, utrzymanie homeostazy wapnia i glutationu oraz podział peroksysomów [50-52,54,55].

Jeszcze bardziej zagadkowym genem związanym z CMT jest IGHMBP2 (ang. Immunoglobulin Mu-Binding Protein 2). Mutacje tego genu prowadzą zwykle do przeponowej postaci rdzeniowego zaniku mięśni (SMARD1, ang. spinal muscular atrophy with respiratory distress type 1) [56]. W 2014 r. wykazano, że mutacje w IGHMBP2 mogą również powodować CMT [57]. W tym wypadku, podobnie jak w przypadku SMARD1, choroba dziedziczona jest autosomalnie recesywnie, jednak jej przebieg jest dużo łagodniejszy [56-58]. Białko IGHMBP2 jest szeroko rozpowszechnioną w tkankach ATP-zależną helikazą zdolną do relaksacji dupleksów DNA, jak i RNA in vitro $[60,61]$. Badania biochemiczne wskazują na zaangażowanie białka IGHMBP2 w transkrypcję, obróbkę pre-mRNA i translację [60-62]. Chociaż dokładny mechanizm prowadzący do degeneracji aksonów zarówno w SMARD1, jak i CMT nie jest poznany, wydaje się, że duże znaczenie odgrywa poziom białka IGHMBP2 w komórkach. W przypadku choroby CMT poziom białka oznaczanego metodą Western blot jest większy niż w SMARD1 $[57,63]$.

\section{PRÓBY FARMAKOTERAPII CHORÓB KRĘGU CHARCOT-MARIE-TOOTH}

Leczenie przyczynowe chorób kręgu CMT jest obecnie niedostępne. Dotychczas udało się jednak określić kilka ce-

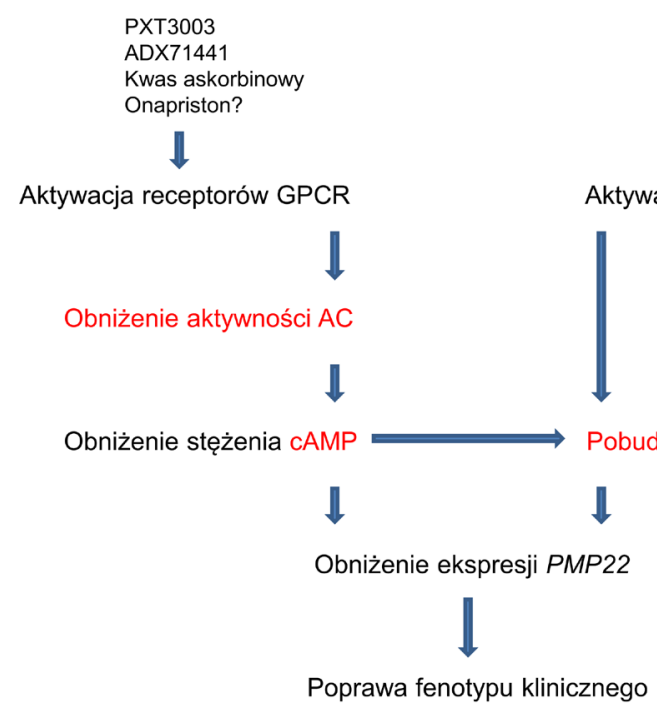

Rycina 2. Główne cele terapeutyczne w chorobie Charcot-Marie-Tooth typu 1A (CMT1A). Ligandy receptorów sprzężonych z białkami G (GPCR) modulują aktywność cyklazy adenylanowej (AC), a przez to poziom cyklicznego adenozynomonofosforanu (cAMP) oraz ekspresje genu PMP22 w komórkach Schwanna. Podobnie neuregulina 1 aktywuje receptor Erb/HER i poprzez pobudzenie szlaku PI3K-AKT lub obniżenie aktywności MEK-ERK również prowadzi do obniżenia ekspresji PMP22. AC - cyklaza adenylanowa; cAMP - cykliczny adenozynomonofosforan; PMP22 - gen obwodowego białka mieliny. lów terapeutycznych na poziomie komórki, które zostały wykorzystane $\mathrm{w}$ badaniach eksperymentalnych oraz próbach klinicznych. Próby te były podejmowane głównie w odniesieniu do najczęstszych postaci dziedzicznych neuropatii ruchowych oraz czuciowych, a więc CMT1A, CMT1B oraz CMT1X.

\section{CHOROBA CHARCOT-MARIE-TOOTH TYPU DEMIELINIZACYJNEGO}

CMT1A jest najlepiej zbadaną, pod względem patomechanizmu i leczenia, dziedziczną neuropatią ruchowo-czuciową. Wykazano wielokrotnie, że liczba kopii genu PMP22 koreluje $\mathrm{z}$ ciężkością przebiegu choroby CMT1A u transgenicznych zwierząt laboratoryjnych $[64,65]$. Na tej podstawie podjęto pierwsze próby terapeutyczne $\mathrm{z}$ użyciem substancji mających na celu obniżenie nadmiernej ekspresji genu PMP22. Zastosowano kwas askorbinowy (witaminę C) [66] oraz antagonistę progesteronu - onapriston [67]. Niestety onapriston nie spełniał kryteriów bezpieczeństwa do zastosowania w badaniach klinicznych [68], a kwas askorbinowy okazał się być nieefektywny w leczeniu pacjentów z chorobą CMT1A [69].

Najnowsza strategia leczenia farmakologicznego obejmuje zastosowanie różnych ligandów dla receptorów sprzężonych z białkami G (GPCR, ang. G protein-coupled receptor), które hamują aktywność cyklazy adenylanowej (AC, ang. adenylyl cyclase) odpowiedzialnej m.in. za regulację ekspresji genu PMP22. W tym miejscu należy zaznaczyć, że kwas askorbinowy oraz hipotetycznie onapriston także wpływają na aktywność AC. Obecnie, jednym z nowszych leków testowanych w trzeciej fazie badania klinicznego jest kombinacja trzech substancji: baklofenu, naltreksonu oraz sorbitolu znanych pod wspólną nazwą PXT 3003, które pobudzają odpowiednio: receptory metabotropowe dla kwasu $\gamma$-aminomasłowego $\left(\mathrm{GABA}_{\mathrm{B}} \mathrm{R}\right)$, podtyp mu $(\mu)$ receptorów opioidowych (MOR) oraz receptory muskarynowe dla acetylocholiny (mACh). W badaniach przedklinicznych wykazano niewielkie obniżenie ekspresji genu PMP22 na poziomie mRNA oraz znaczną poprawę w mielinizacji aksonów i w testach behawioralnych u transgenicznych szczurów CMT1A po podaniu PXT 3003 [70].

Kolejną testowaną w badaniach przedklinicznych substancją dedykowaną dla chorych z CMT1A jest związek chemiczny ADX71441, będący pozytywnym modulatorem allosterycznym (czyli takim, który wiąże się $\mathrm{z}$ receptorem $\mathrm{w}$ innym miejscu niż substancja endogenna) receptorów $\mathrm{GABA}_{B}$. W odróżnieniu od modulatorów ortosterycznych (tzn. takich, które współzawodniczą o dostęp do miejsca wiązania z endogenną substancją), tj. PXT 3003, ADX71441 działa silniej i bardziej specyficznie. Po podaniu ADX71441 obserwowano obniżenie ekspresji 
PMP22 na poziomie mRNA w nerwach obwodowych transgenicznych szczurów CMT1A, a także obniżenie liczby nieprawidłowo zmielinizowanych aksonów oraz zwiększenie wartości amplitud odpowiedzi z nerwów obwodowych (CMAP, ang. compound muscle action potentials) w badaniu elektromiograficznym, świadczących o zwiększeniu liczby funkcjonalnych aksonów, w porównaniu do grupy kontrolnej [71]. ADX71441 okazał się również skuteczny w leczeniu chorób niezwiązanych z CMT, tj. pęcherz nadreaktywny, a także lęk, ból oraz spastyczność i został zatwierdzony do I fazy badań klinicznych w tych schorzeniach $[72,73]$.

Skuteczną substancją wydaje się też być neuregulina 1 (NRG 1). Ostatnie badanie wykazało, że podanie tego białka szczurom z CMT1A we wczesnych etapach rozwoju postnatalnego zapobiega utracie aksonów u zwierząt dorosłych. $\mathrm{Z}$ drugiej jednak strony, jako antagonista receptorów ErbB/ HER, których zwiększoną ekspresję stwierdza się $\mathrm{w}$ wielu nowotworach, NRG1 jest potencjalnym czynnikiem kancerogennym [74].

Wartym podkreślenia wydaje się fakt, że wszystkie przedstawione dotąd strategie terapeutyczne mają wspólny cel terapeutyczny, którym jest AC. Modulowanie jej aktywności jest kluczowe w utrzymaniu równowagi pomiędzy proliferacją, a różnicowaniem komórek Schwanna, m.in. poprzez regulację ekspresji genu PMP22 [75]. AC, oprócz tego, wpływa na wiele szlaków transdukcji sygnałów tj. PI3K-AKT, MEK-ERK oraz integruje bodźce pochodzące $z$ różnych receptorów, np. kinaz tyrozynowych [76]. Dlatego modulacja jej aktywności może przynieść pozytywne skutki także dla pacjentów cierpiących na inne typy CMT, nie tylko CMT1A. Pokazano, że wzmożona sygnalizacja MEK/ ERK może prowadzić do uszkodzenia nerwów oraz zwyrodnienia aksonów w wyniku fagocytozy przeprowadzanej przez makrofagi na skutek zwiększenia ekspresji białka chemotaktycznego monocytów 1 (CCL2), które oddziałuje z czynnikiem stymulującym tworzenie kolonii (CSF-1) [74]. Zastosowanie antagonisty CSF-1 w mysich modelach CMT1A, CMT1B oraz CMT1X spowodowało obniżenie liczby makrofagów w endoneurium (warstwa tkanki łącznej, otaczająca osłonkę mielinową włókien nerwowych) we wszystkich grupach oraz dodatkowo poprawiło wartości CMAP, a także zwiększyło siłę uścisku w badaniach behawioralnych w obrębie grup CMT1B i CMT1X, ale nie w grupie CMT1A [77]. Badania te, mogą okazać się pomocne w identyfikacji nowych celów terapeutycznych.

Patogeneza różnych form CMT, włączając CMT1B jest również związana z odpowiedzią UPR komórki na nieprawidłowo zwinięte białka [78]. Sefina 1 (selektywny inhibitor holofosfatazy) jest nowym lekiem, który zapobiega defektom ruchowym, morfologicznym oraz molekularnym $\mathrm{w}$ przypadku dwóch różnych chorób związanych z zaburzeniem fałdowania białek: CMT oraz stwardnienia zanikowego bocznego [79].

\section{CHOROBA CHARCOT-MARIE-TOOTH TYPU AKSONALNEGO}

Rozwój strategii terapeutycznych związanych z CMT typu aksonalnego skupia się głównie na mutacjach w obrębie dwóch genów: MFN2 oraz HSPB1, które są odpowie- dzialne kolejno za wystapienie CMT2A oraz CMT2F. W modelu komórkowym choroby CMT2A, w którym wykorzystano pierwotne kultury mysich neuronów czuciowych, zaobserwowano zahamowanie zwyrodnienia aksonalnego przez nadprodukcję mitofuzyny 1 (MFN1) oraz zastosowanie blokerów kanałów sodowych [80]. Z kolei u myszy z mutacją prowadzącą do substytucji Thr105Met w białku MFN2 zastosowanie agonistów mitofuzyny spowodowało normalizację transportu aksonalnego mitochondriów w nerwach kulszowych [81]. Z kolei mutacje HSPB1 powodują obniżenie poziomu acetylowanej alfa tubuliny $\mathrm{w}$ obrębie nerwów obwodowych, co prowadzi do zaburzenia transportu mitochondriów w aksonach. Można temu zapobiec stosując inhibitor białka HDAC6, które należy do rodziny deacetylaz histonowych (HDAC), ale w odróżnieniu od pozostałych białek tej rodziny nie jest ono zaangażowane w modyfikację posttranslacyjną białek histonowych, a zamiast tego reguluje stan acetylacji innych białek docelowych [82]. $\mathrm{W}$ badaniach $\mathrm{z}$ użyciem modelu in vitro choroby CMT2F pokazano, że podanie selektywnych inhibitorów HDAC6 znacznie poprawiło transport aksonalny mitochondriów [83].

\section{MODEL DROŻDŻOWY W BADANIACH NAD PATOGENEZA I TERAPIA EKSPERYMENTALNĄ POLINEUROPATII GENETYCZNIE UWARUNKOWANYCH}

Drożdże Saccharomyces cerevisiae są bardzo dobrze poznanym i szeroko stosowanym organizmem modelowym. Posiadają wiele zalet, z których najważniejsze to prostota i niska cena hodowli, krótki czas generacji, podatność na manipulację genetyczną oraz możliwość oddychania zarówno na drodze fermentacji, jak i z wykorzystaniem tlenu. Niezwykle istotne jest też znaczne podobieństwo podstawowych procesów komórkowych i białek w nich uczestniczących pomiędzy drożdżami a ludźmi do tego stopnia, że niektóre ludzkie geny mogą komplementować defekty spowodowane brakiem natywnych genów drożdżowych [84-88]. Nic więc dziwnego, że drożdże są szeroko wykorzystywane do badania mechanizmu powstania licznych chorób [89], w tym m. in. chorób mitochondrialnych [90] czy neurodegeneracyjnych $[91,92]$.

Pomimo, że polineuropatie genetycznie uwarunkowane dotykają bardzo wyspecjalizowanych części komórki nerwowej, jakimi są aksony i osłonka mielinowa, niektóre z mutacji wywołujących uszkodzenie nerwu obwodowego znajdują się $\mathrm{w}$ genach kodujących białka uczestniczące $\mathrm{w}$ podstawowych procesach komórkowych, takich jak: metabolizm fosfatydyloinozytoli (FIG4), fuzja mitochondriów (MFN2), aminoacylacja tRNA (syntetazy aminoacylo-tRNA (ARS): GARS, YARS, AARS, HARS, KARS oraz MARS) transport pęcherzykowy (endosomalny) czy dynamika błon (DNM2) (Ryc. 1). Daje to możliwość zastosowania modelu drożdżowego do badania etiologii wielu neuropatii, określania patogenności poszczególnych mutacji oraz ich charakterystyki funkcjonalnej.

Drożdże są powszechnie wykorzystywane do testowania fenotypu utraty funkcji przez syntetazy aminoacylo-tRNA [35,36,38,93-95]. W tym teście drożdżowe ortologi 
typu dzikiego (podane w nawiasach) GARS (GRS1), YARS (TYS1), AARS (ALA1), HARS (HTS1), KARS (KRS1) i MARS (MES1) zostają usunięte i zastąpione allelem niosącym mutację wykrytą u chorych. Geny z rodziny ARS są kluczowe do przeżycia komórki, drożdże nie są w stanie rosnąć $\mathrm{z}$ nieaktywnymi allelami. Tak więc pośrednią miarą funkcji ARS jest żywotność komórek drożdżowych. Oczywiście taka analiza ma swoje ograniczenia, jednakże zmutowane allele, które powodują utratę funkcji w drożdżowych testach komplementacji, na ogół wykazują również utratę aktywności enzymatycznej w testach in vitro [38,40,93,96-98].

Drożdże mogą posłużyć również do charakterystyki aktywności białka, która jest zaburzona przez substytucje aminokwasowe prowadzące do neuropatii. Badania $\mathrm{z}$ wykorzystaniem drożdżowej mitofuzyny Fzo1 (MNF1/2 u ludzi), wykazały, że różne mutacje występujące u chorych, mają różny wpływ na funkcjonowanie białka, począwszy od subtelnych zmian morfologicznych w sieci mitochondrialnej i w fuzji mitochondriów, poprzez zaburzenia w hydrolizie GTP, do zwiększenia poziomu białka w komórce na skutek zaburzeń jego degradacji. Wykazano również, że nie wszystkie zbadane substytucje mają przewidywany wpływ na funkcję białek, w których się znajdują, np. mutacja w domenie GTPazy nie tylko zakłóca hydrolizę GTP i fuzję błon, ale prowadzi również do zmiany stabilności białka [99]. Innymi przykładami są badania nad drożdżową fosfatazą 3-fosforanu fosfatydyloinozytolu, Fig4, gdzie wykazano, że substytucja I59T (I41T u ludzi) upośledza zdolność Fig4 do aktywacji kinazy Fab1/PIKfyve w drożdżach [100] oraz badania nad drożdżową dynaminą Vps1 (DYN1/2 u ludzi), gdzie różne zmiany wpływają na różne aspekty funkcjonowania tego białka, takie jak oligomeryzacja białka, aktywność w procesie uwalniania pęcherzyka endocytarnego od błony komórkowej, czy specyficzność wiązania lipidów [101].

Drożdże są również przydatne do badania oddziaływań białko-białko, a także wpływu poszczególnych mutacji na te oddziaływania. Przy użyciu drożdżowego systemu dwuhybrydowego wykazano, że ludzkie białko GDAP1, kodowane przez gen, którego mutacje warunkują wystąpienie CMT, oddziałuje z $\beta$-tubuliną oraz białkami zaangażowanymi w transport (caytaxin i RAB6B) [55,85]. Zidentyfikowano również fragment GDAP1 odpowiedzialny za jego oddziaływanie z tubuliną oraz wykazano wpływ negatywnych zmian w białku GDAP1 na to oddziaływanie [85]. Używając systemu dwuhybrydowego wykazano również, że mutacja skutkująca substytucją I41T w ludzkiej fosfatazie FIG4 znacząco zaburza jej interakcję z aktywatorem kinazy PIKfyve, VAC14 [102].

Ze względu na niewielki koszt i łatwość hodowli, a także na szybki czas generacji, drożdże są chętnie wykorzystywane do analiz wielkoskalowych, które mają na celu znalezienie czynników genetycznych czy związków chemicznych odpowiedzialnych za modyfikację fenotypu spowodowanego mutacjami. Pozwala to na identyfikację potencjalnych celów terapeutycznych czy substancji aktywnych mogących stać się w przyszłości lekami. Znalezione w ten sposób cząsteczki chemiczne bądź geny okazują się działać również w bardziej złożonych modelach [103-106]. Drożdże moż- na więc wykorzystać w analizach wielkoskalowych, które umożliwią w przyszłości opracowanie terapii polineuropatii genetycznie uwarunkowanych. Z drugiej strony możliwe są badania przesiewowe mające na celu zidentyfikowanie związków, czy też alleli, które mogą wzmacniać fenotyp choroby. Jak wspomniano wyżej, CMT jest chorobą niezwykle heterogenną zarówno pod względem genetycznym, jak i klinicznym. W dodatku identyczne mutacje w tym samym genie charakteryzują się duża zmiennością fenotypową pomiędzy poszczególnych pacjentami. Sugeruje to, że dużą rolę w wystąpieniu objawów może odgrywać tło genetyczne. W dobie sekwencjonowania nowej generacji zbadanie podłoża genetycznego poszczególnych pacjentów nie stanowi już dużego wyzwania technicznego, jednakże pojawia się problem z interpretacją danych. Badania na drożdżach mogą ułatwić określić, które allele mogą zaostrzać objawy choroby. Podobnie, wielkoskalowe badania przesiewowe mogą pomóc zidentyfikować cząsteczki chemiczne, które mogą okazać się wyjątkowo toksyczne dla komórek pacjentów niosących poszczególne mutacje. Znalezienie takich związków pozwoliłoby nie tylko na lepsze leczenie takich pacjentów oraz unikanie pogłębienia choroby, ale mogłoby też okazać się przydatne w rozwikłaniu mechanizmów molekularnych prowadzących do wystąpienia polineuropatii.

Powyższe przykłady ilustrują, że drożdże stanowią użyteczny model do badania etiopatogenezy molekularnej polineuropatii genetycznie uwarunkowanych. Ponadto model drożdżowy może posłużyć do identyfikacji mutacji patogennych, analizy mechanizmów molekularnych prowadzących do rozwoju choroby, a także do poszukiwania nowych substancji leczniczych oraz toksycznych.

\section{PRÓBY TERAPII GENOWEJ W CMT}

Celem terapii genowej jest leczenie choroby poprzez przeniesienie materiału genetycznego do komórek somatycznych organizmu [107]. Metody dostarczania materiału genetycznego na ogół oparte są na wykorzystaniu nośników wirusowych, bądź niewirusowych, tj. liposomów czy nanocząsteczek. Terapia genowa wydaje się stanowić podejście terapeutyczne $\mathrm{z}$ dużym potencjałem leczniczym w niektórych chorobach układu nerwowego i jest możliwa tylko dzięki wcześniejszym badaniom podstawowym i zrozumieniu procesów prowadzących do powstania tych chorób oraz ciągłemu rozwojowi metod biologii molekularnej poprzez projektowanie coraz lepszych wektorów terapeutycznych oraz metod ich dostarczania.

Większość wektorów wirusowych wykorzystywanych w terapiach genowych układu nerwowego, zarówno centralnego jak i obwodowego, opiera się na wykorzystaniu kilku rodzajów wirusów. Lentiwirusy (LV) i wirusy opryszczki (HSV) mają naturalną zdolność infekowania układu nerwowego, wektory oparte zaś na adenowirusach (Ad) czy wirusach towarzyszących adenowirusom (AAV) w zależności od typu wektora i odpowiednich modyfikacji mogą z różną efektywnością być również wprowadzane do tkanki nerwowej $[108,109]$.

Terapia genowa stanowi obiecujące leczenie wielu chorób monogenowych, w tym także chorób nerwowo- 
-mięśniowych. Przykładem są próby terapii genowej $\mathrm{w}$ zwierzęcych modelach dziedzicznej neuropatii CMT1X, powodowanej mutacjami w genie GJB1. Wektor lentiwirusowy z genem GJB1 typu dzikiego dostarczany bądź poprzez podanie bezpośrednio do nerwu kulszowego bądź dooponowo u myszy GJB1(-/-), wykazywał ekspresję w około 50\% komórek Schwanna [109-111]. Zanotowano znaczące zmniejszenie liczby nieprawidłowo zmielinizowanych włókien nerwowych oraz zmniejszenie towarzyszącego stanu zapalnego $[109,111]$. Myszy po terapii wektorem LV-GJB1 wykazywały lepszą kurczliwość włókien mięśnia czworogłowego, poprawę przewodzenia w nerwie kulszowym i znaczną poprawę motoryki [111]. Podanie dooponowe wektora LV-GJB1 prowadziło do dostarczenia genu do komórek Schwanna nie tylko $\mathrm{w}$ bezpośrednim obszarze iniekcji, jak ma to miejsce $\mathrm{w}$ przypadku bezpośredniego podania do nerwu kulszowego, ale szeroko do korzeni nerwu lędźwiowego oraz na całej długości nerwu udowego i kulszowego [111]. Dooponowe iniekcje są rutynowo stosowane w różnych badaniach klinicznych, dlatego też ta metoda podawania wydaje się bardzo obiecująca w terapii genowej polineuropatii mimo jej inwazyjnego charakteru.

Wirusy AAV wykorzystano w badaniach przedklinicznych m.in. w próbach leczenia przeponowej postaci rdzeniowego zaniku mięśni (SMARD1) [112]. Jak wspomniano wyżej, choroba spowodowana jest mutacjami w genie IGHMBP2 i dziedziczona w sposób autosomalny recesywny, podobnie jak CMT2S spowodowane mutacjami w tym samych genie [57]. Gen typu dzikiego IGHMBP2 na wektorze AAV9 wprowadzony drogą iniekcji do mięśnia brzuchatego łydki u myszy jest w stanie zastąpić defektywny gen i przywrócić odpowiedni poziom białka w komórce. Zanotowano $\mathrm{u}$ tych myszy poprawę funkcji motorycznych, wydłużenie czasu przeżycia, zmniejszenie zmian patologicznych w ośrodkowym układzie nerwowym, mięśniach szkieletowych oraz sercu. Usprawnieniu uległy połączenia nerwowo-mięśniowe, a także wzrosła wielkość włókien mięśniowych. W hodowlach komórkowych uwidoczniono wyraźne zmniejszenie ubytku aksonów oraz ich wydłużenie [112]. Prowadzone badania u chorych ze SMARD1, stanowią również szansę na skuteczną terapię w przypadku chorych z CMT2S. Jednak skuteczność tej terapii jest silnie zależna od dawki i przy wysokiej podaży wektora AAV9-IGHMBP2, może mieć skutki negatywne [63]. Zatem niezwykle ważne przy tej formie leczenia jest bardzo ścisłe dobranie dawki podawanego wektora, tak aby leczenie mogło być skutecznie lecz nietoksyczne.

Wykazano, że podanie myszom Trembler (Tr-J), będącym modelem choroby CMT1A powodowanej mutacją punktową w genie PMP22, białka neurotrofiny 3 (NT-3), zwiększało $u$ nich remielinizację i znacznie usprawniało zwierzęta motorycznie [113]. Dlatego też prowadzone są dalsze badania nad tą cząsteczką. Podstawowym jednak problemem z leczeniem farmakologicznym przy pomocy NT-3 jest jej bardzo krótki czas półtrwania oraz dostępność, dlatego niemożliwe jest zastosowanie długoterminowego leczenia. Terapia genowa stała się tu skutecznym rozwiązaniem problemu. Po domięśniowym podaniu u myszy Tr-J wektora AAV1 niosącego gen NT-3, stwierdzono wyraźny poziom NT-3 w surowicy krwi myszy oraz wykazano poprawę ich funkcji motorycznych, wzrost poziomu remielinizacji oraz zwiększenie gęstości włókien mielinowych i poprawę $w$ badaniach neurograficznych [114]. Próbę terapeutyczną z zastosowaniem AAV1-NT-3 zastosowano z dobrym skutkiem również w mysim modelu immunologicznie uwarunkowanej polineuropatii CIDP (ang. chronic inflammatory demyelinating polyneuropathy), po podaniu do mięśnia brzuchatego łydki myszy CIDP wektora AAV1 niosącego gen NT-3 [115].

Wektory oparte o HSV w ostatnich latach były wykorzystane w szeregu badań przedklinicznych w leczeniu różnych modeli neuropatii. Podskórne podanie wektora HSV niosącego gen NT-3, powodowało zachowanie amplitudy potencjałów czynnościowych oraz szybkości przewodzenia w modelu degeneracyjnym dużych włókien nerwowych wywołanym podaniem pirydoksyny. Podobnie ochronne działanie miało wprowadzenie HSV-NT-3 lub genu NGF w przypadku neuropatii indukowanej cisplatyną oraz wprowadzenie genów NGF, VEGF lub erytropoetyny, w modelu indukowanej neuropatii cukrzycowej [116].

Ponieważ użycie wektorów wirusowych potencjalnie może nieść za sobą efekty uboczne, np. aktywację odpowiedzi układu immunologicznego czy neurotoksyczność, rozwijają się badania nad wprowadzaniem do komórek genów poprzez nośniki niewirusowe np. nanocząsteczki. Opracowano cząsteczkę o tropizmie do tkanki nerwowej opartą na poli-etylenoiminie połączonej z nietoksycznym C-końcem toksyny tężca (PEISH-HC). Śródskórne podanie do łapy szczurów tej cząsteczki połączonej z genem GFP (kodującym białko zielonej fluorescencji), prowadziło do ekspresji w neuronach zwojów korzeni grzbietowych (DRG) na poziomie L4 i L5 sięgającą nawet 64\% [117]. Badania nie wykazały znaczących efektów ubocznych stosowania nośnika opartego na PEISH-HC, zatem tego typu cząsteczki stanowią atrakcyjną alternatywę do nośników wirusowych w terapii genowej polineuropatii.

Terapia genowa polega jednak nie tylko na wprowadzaniu nowych genów, ale również modyfikacji ekspresji genów. Terapia antysensownymi nukleotydami (AON) w chorobach nerwowo-mięśniowych jest szeroko rozważaną formą leczenia, szczególnie w przypadku patologii, u których podstaw leży bądź nadekspresja genu, jak ma to miejsce w przypadku CMT1A wywołanego duplikacją genu PMP22, bądź zbyt niska ekspresja genu jak ma to miejsce w rdzeniowym zaniku mięśni (SMA). W przypadku choroby CMT1A zależy nam na częściowym wyciszeniu ekspresji genu PMP22. Prowadzone in vitro badania z nukleotydami tworzącymi tripleksy (TFO), które wiążą się z sekwencjami promotorowymi P1 i P2 genu PMP22, były pierwszymi próbami opracowania metody wyciszania genu PMP22 [118]. Ostatnie badania wykazały użyteczność takiego leczenia w przypadku mysich modeli CMT1A [119]. Podanie śródskórne zmodyfikowanych, antysensownych nukleotydów powodowało przywrócenie szybkości przewodzenia i amplitudy potencjałów czynnościowych oraz odpowiedniego stopnia mielinizacji w nerwach obwodowych do poziomu obserwowanego u myszy zdrowych [120]. 
Obiecujące wyniki uzyskano w modelu myszy Tr-J, z mutacją $\mathrm{w}$ genie PMP22. W przypadku mutacji punktowych dziedziczonych w sposób autosomalnie dominujący badacze opracowali allelo-specyficzne małe interferujące RNA (siRNA), które specyficznie wyciszają ekspresję defektywnego allelu genu PMP22. Dootrzewnowe podanie siRNA 6-dniowym myszom Tr-J, spowodowało znaczne usprawnienie ich funkcji motorycznych, zwiększenie masy mięśniowej oraz poprawę wyników w badaniach elektroneurograficznych [120].

Terapie opartą na transpozonach wykorzystano m.in. $\mathrm{w}$ próbach terapii ex vivo $\mathrm{w}$ przypadku dystrofii mięśniowych. Transpozon SB100X wykorzystano do transferu genu do komórek satelitarnych i mioblastów [121]. Stwierdzono przydatność tego systemu do stabilnego transferu cDNA dysferliny i mikrodystrofiny w modelu mysim [121]. Duże nadzieje daje wykorzystanie systemu transpozonowego do transferu genów nie do mioblastów czy komórek satelitarnych, ale do mesoangioblastów (MAB), które mają zdolność do migracji przez ściany naczyń krwionośnych oraz do różnicowania w linie miogenne. Transplantacja poddanych terapii genowej komórek MAB in vivo w modelach dystroficznych może wspomagać regenerację mięśni i łagodzić objawy choroby. Prowadzone są również prace nad wykorzystaniem genetycznie modyfikowanych indukowanych pluripotencjalnych komórek macierzystych iPSC [121].

\section{PODSUMOWANIE}

Polineuropatie genetycznie uwarunkowane zostały opisane w literaturze naukowej dopiero pod koniec XIX wieku. Do lat dziewięćdziesiątych XX wieku nie znano ani jednego genu, którego mutacje powodują CMT. W pierwszej dekadzie XXI wieku doszło do "eksplozji” odkryć w zakresie genetyki CMT a obecnie znanych jest już ponad 80 genów związanych z tą grupą chorób. Charakterystyka patogenezy CMT jest wciąż niepełna. W przypadku niektórych genów (PMP22, GJB1) zaawansowany poziom badań nad patogenezą molekularną umożliwił rozpoczęcie prac nad terapią eksperymentalną tych chorób. $W$ innych przypadkach (GDAP1, IGHMBP2) znajomość patogenezy molekularnej jest wciąż ograniczona, a nawet niektóre doniesienia naukowe zawierają sprzeczne i nieuporządkowane dane. Poznanie heterogenności genetycznej CMT umożliwiło charakterystykę poszczególnych odmian polineuropatii. Możliwość określenia mutacji odpowiedzialnej za wystąpienie jednej z odmian CMT otworzyła drogę do poradnictwa genetycznego. Szacuje się, że wciąż w około $50 \%$ przypadków przyczyna polineuropatii pozostaje nieznana. Nie można wykluczyć, że niektóre z nich wywołane są poprzez kilka mutacji (dziedziczenie wielogenowe) lub przez mutacje zlokalizowane $\mathrm{w}$ regionach regulatorowych genomu lub mutacje o charakterze rearanżacji genomowych. Pomimo widocznego postępu w badaniach nad leczeniem przyczynowym CMT nie można pominąc leczenia objawowego, które również w pewnym stopniu zależy od wyniku badania genetycznego. W przeciwieństwie do lat dziewięćdziesiątych XX wieku charakteryzujących się koncentracją badań nad CMT w konsorcjach zrzeszających ośrodki badawcze (uniwersytet $\mathrm{w}$ Antwerpii) prowadzone obecnie badania nad tą grupą cho- rób mają charakter rozproszony. Trudno więc ocenić niejako "z lotu ptaka” poziom zaawansowania badań nad CMT. Wydaje się, że w najbliższej przyszłości należy spodziewać się opracowania nowych algorytmów leczenia w polineuropatiach występujących stosunkowo często (CMT1A, CMT1X). Zupełnie nieprzewidywalna jest perspektywa terapeutyczna w polineuropatiach bardzo rzadkich, wywołanych mutacjami genów GDAP1, IGHMBP2 czy innych. Z uwagi na dość łagodny obraz kliniczny większości polineuropatii i ich rzadkie występowanie nie znajdują się one $\mathrm{w}$ centrum uwagi przemysłu farmaceutycznego. Można mieć jednak nadzieję, że dynamiczny rozwój nowych technologii przyczyni się do przyspieszenia wprowadzenia do praktyki leczenia przyczynowego polineuropatii genetycznie uwarunkowanych.

\section{PIŚMIENNICTWO}

1. Skre H (1974) Genetic and clinical aspects of Charcot-Marie-Tooth's disease. Clin Genet 6: 98-118

2. Barreto LC, Oliveira FS, Nunes PS, de França Costa IM, Garcez CA, Goes GM, Neves EL, de Souza Siqueira Quintans J, de Souza Araújo AA (2016) Epidemiologic study of Charcot-Marie-Tooth disease: a systematic review. Neuroepidemiology 46: 157-165

3. Jędrzejowska H, Drac H (2004) Neuropatie dziedziczne, W: Kozubski W, Liberski PP (red) Choroby układu nerwowego. PZWL, Warszawa, str. 286-295

4. Timmerman V, Strickland AV, Züchner S (2014) Genetics of Charcot-Marie-Tooth (CMT) disease within the frame of the human genome project success. Genes 5: 13-32

5. Drew AP, Zhu D, Kidambi A, Ly C, Tey S, Brewer MH, Ahmad-Annuar A, Nicholson GA, Kennerson ML (2015) Improved inherited peripheral neuropathy genetic diagnosis by whole-exome sequencing. Mol Genet Genomic Med 3: 143-154

6. Hartley T, Wagner JD, Warman-Chardon J, Tétreault M, Brady L, Baker S, Tarnopolsky M, Bourque PR, Parboosingh JS, Smith C, McInnes B, Innes AM, Bernier F, Curry CJ, Yoon G, Horvath GA, Bareke E, Gillespie M; FORGE Canada Consortium, Care4Rare Canada Consortium, Majewski J, Bulman DE, Dyment DA, Boycott KM (2018) Whole-exome sequencing is a valuable diagnostic tool for inherited peripheral neuropathies: outcomes from a cohort of 50 families. Clin Genet 93: 301-309

7. Cutrupi AN, Brewer MH, Nicholson GA, Kennerson ML (2018) Structural variations causing inherited peripheral neuropathies: a paradigm for understanding genomic organization, chromatin interactions and gene dysregulation. Mol Genet Genomic Med 6: 422-433

8. Dyck PJ, Lambert EH (1968) Lower motor and primary sensory neuron diseases with peroneal muscular atrophy. II. Neurologic, genetic, and electrophysiologic findings in various neuronal degenerations. Arch Neurol 18: 619-625

9. Pareyson D, Marchesi C (2009) Diagnosis, natural history, and management of Charcot-Marie-Tooth disease. Lancet Neurol 8: 654-667

10. McCorquodale D, Pucillo EM, Johnson NE (2016) Management of Charcot-Marie-Tooth disease: improving long-term care with a multidisciplinary approach. J Multidiscip Healthc 9: 7-19

11. Brennan KM, Bai Y, Shy ME (2015) Demyelinating CMT-what's known, what's new and what's in store? Neurosci Lett 596: 14-26

12. Amici SA, Dunn WA, Notterpek L (2007) Developmental abnormalities in the nerves of peripheral myelin protein 22-deficient mice. J Neurosci Res 85: 238-249

13. Guo J, Wang L, Zhang Y, Wu J, Arpag S, Hu B, Imhof BA, Tian X, Carter BD, Suter U, Li J (2014) Abnormal junctions and permeability of myelin in PMP22-deficient nerves. Ann Neurol 75: 255-265

14. Sancho S, Young P, Suter U (2001) Regulation of Schwann cell proliferation and apoptosis in PMP22-deficient mice and mouse models of Charcot-Marie-Tooth disease type 1A. Brain 124: 2177-2187 
15. Chance PF, Alderson MK, Leppig KA, Lensch MW, Matsunami N, Smith B, Swanson PD, Odelberg SJ, Disteche CM, Bird TD (1993) DNA deletion associated with hereditary neuropathy with liability to pressure palsies. Cell 72: 143-151

16. Bergoffen J, Scherer SS, Wang S, Scott MO, Bone LJ, Paul DL, Chen K, Lensch MW, Chance PF, Fischbeck KH (1993) Connexin mutations in X-linked Charcot-Marie-Tooth disease. Science 262: 2039-2042

17. Kleopa KA, Sargiannidou, I (2015) Connexins, gap junctions and peripheral neuropathy. Neurosci Lett 596: 27-32

18. Kumar NM, Gilula NB (1986) Cloning and characterization of human and rat liver cDNAs coding for a gap junction protein. J Cell Biol 103: 767-776

19. Paul DL (1986) Molecular cloning of cDNA for rat liver gap junction protein. J Cell Biol 103: 123-134

20. Meier C, Dermietzel R, Davidson KGV, Yasumura T, Rash JE (2004) Connexin32-containing gap junctions in Schwann cells at the internodal zone of partial myelin compaction and in Schmidt-Lanterman incisures. J Neurosci 24: 3186-3198

21. Scherer SS, Deschênes SM, Xu YT, Grinspan JB, Fischbeck KH, Paul DL (1995) Connexin32 is a myelin-related protein in the PNS and CNS. J Neurosci 15: 8281-8294

22. Hayasaka K, Himoro M, Sato W, Takada G, Uyemura K, Shimizu N, Bird TD, Conneally PM, Chance PF (1993) Charcot-Marie-Tooth neuropathy type $1 \mathrm{~B}$ is associated with mutations of the myelin $\mathrm{P} 0$ gene. Nat Genet 5: 31-34

23. Trapp BD, Itoyama Y, Sternberger NH, Quarles RH, Webster H (1981) Immunocytochemical localization of P0 protein in Golgi complex membranes and myelin of developing rat Schwann cells. J Cell Biol 90: $1-6$

24. Greenfield S, Brostoff S, Eylar EH, Morell P (1973) Protein composition of myelin of the peripheral nervous system. J Neurochem 20: 12071216

25. Lemke G, Axel R. (1985) Isolation and sequence of a cDNA encoding the major structural protein of peripheral myelin. Cell 40: 501-508

26. Bai Y, Wu X, Brennan KM, Wang DS, D'Antonio M, Moran J, Svaren J, Shy ME (2018) Myelin protein zero mutations and the unfolded protein response in Charcot Marie Tooth disease type 1B. Ann Clin Transl Neurol 5: 445-455

27. Züchner S, Mersiyanova IV, Muglia M, Bissar-Tadmouri N, Rochelle J, Dadali EL, Zappia M, Nelis E, Patitucci A, Senderek J, Parman Y, Evgrafov O, Jonghe PD, Takahashi Y, Tsuji S, Pericak-Vance MA, Quattrone A, Battaloglu E, Polyakov AV, Timmerman V, Schröder JM, Vance JM (2004) Mutations in the mitochondrial GTPase mitofusin 2 cause Charcot-Marie-Tooth neuropathy type 2A. Nat Genet 36: 449451.

28. Kawalec M, Kotruchow K, Kochański A and Zabłocka B (2011) Mitofusin 2 as a crucial peripheral nervous system protein and a common regulator of cell metabolism. Postepy Biochem 57: 215-221

29. Stuppia G, Rizzo F, Riboldi G, Del Bo R, Nizzardo M, Simone C, Comi GP, Bresolin N, Corti S (2015) MFN2-related neuropathies: clinical features, molecular pathogenesis and therapeutic perspectives. J Neurol Sci 356: 7-18

30. Chen H, McCaffery JM, Chan DC (2007) Mitochondrial fusion protects against neurodegeneration in the cerebellum. Cell 130: 548-562

31. Filadi R, Pendin Di, Pizzo P (2018) Mitofusin 2: from functions to disease. Cell Death Dis 9: 330

32. Misko A, Jiang S, Wegorzewska I, Milbrandt J, Baloh H (2010) Mitofusin 2 is necessary for transport of axonal mitochondria and interacts with the Miro/Milton complex. J Neurosci 30: 4232-4240

33. Santel A, Fuller MT (2001) Control of mitochondrial morphology by a human mitofusin. J Cell Sci 114: 867-874

34. Antonellis A, Ellsworth RE, Sambuughin N, Puls I, Abel A, Lee-Lin SQ, Jordanova A, Kremensky I, Christodoulou K, Middleton LT, Sivakumar K, Ionasescu V, Funalot B, Vance JM, Goldfarb LG, Fischbeck KH, Green ED (2003) Glycyl tRNA synthetase mutations in Charcot-Marie-Tooth disease type 2D and distal spinal muscular atrophy type V. Am J Hum Genet 72: 1293-1299
35. Gonzalez M, McLaughlin H, Houlden H, Guo M, Yo-Tsen L, Hadjivassilious M, Speziani F, Yang XL, Antonellis A, Reilly MM, Züchner S, Inherited Neuropathy Consortium (2013) Exome sequencing identifies a significant variant in methionyl-tRNA synthetase (MARS) in a family with late-onset CMT2. J Neurol Neurosurg Psychiatry 84: 1247-1249

36. Jordanova A, Irobi J, Thomas FP, Van Dijck P, Meerschaert K, Dewil M, Dierick I, Jacobs A, De Vriendt E, Guergueltcheva V, Rao CV, Tournev I, Gondim FA, D'Hooghe M, Van Gerwen V, Callaerts P, Van Den Bosch L, Timmermans JP, Robberecht W, Gettemans J, Thevelein JM, De Jonghe P, Kremensky I, Timmerman V (2006) Disrupted function and axonal distribution of mutant tyrosyl-tRNA synthetase in dominant intermediate Charcot-Marie-Tooth neuropathy. Nat Genet 38: 197-202

37. Latour P, Thauvin-Robinet C, Baudelet-Méry C, Soichot P, Cusin V, Faivre L, Locatelli MC, Mayençon M, Sarcey A, Broussolle E, Camu W, David A, and Rousson R (2010) A major determinant for binding and aminoacylation of tRNAAla in cytoplasmic alanyl-tRNA synthetase is mutated in dominant axonal Charcot-Marie-Tooth disease. Am J Hum Genet 86: 77-82

38. McLaughlin HM, Sakaguchi R, Liu C, Igarashi T, Pehlivan D, Chu K, Iyer R, Cruz P, Cherukuri PF, Hansen NF, Mullikin JC, NISC Comparative Sequencing Program, Biesecker LG, Wilson TE, Ionasescu V, Nicholson G, Searby C, Talbot K, Vance JM, Züchner S, Szigeti K, Lupski JR, Hou YM, Green ED, Antonellis A (2010) Compound heterozygosity for loss-of-function lysyl-tRNA synthetase mutations in a patient with peripheral neuropathy. Am J Hum Genet 87: 560-566

39. Vester A, Velez-Ruiz G, McLaughlin HM, NISC Comparative Sequencing Program, Lupski JR, Talbot K, Vance JM, Züchner S, Roda RH, Fischbeck KH, Biesecker LG, Nicholson G, Beg AA, Antonellis A (2013) A loss-of-function variant in the human histidyl-tRNA synthetase (HARS) gene is neurotoxic in vivo. Hum Mutat 34: 191-199

40. Storkebaum E (2016) Peripheral neuropathy via mutant tRNA synthetases: inhibition of protein translation provides a possible explanation. Bioessays 38: 818-829

41. Niehues S, Bussmann J, Steffes G, Erdmann I, Köhrer C, Sun L, Wagner M, Schäfer K, Wang G, Koerdt SN, Stum M, Jaiswal S, RajBhandary UL, Thomas U, Aberle H, Burgess RW, Yang XL, Dieterich D, Storkebaum E (2015) Impaired protein translation in Drosophila models for Charcot-Marie-Tooth neuropathy caused by mutant tRNA synthetases. Nat Commun 6: 7520

42. He W, Bai G, Zhou H, Wei N, White NM, Lauer J, Liu H, Shi Y, Dumitru CD, Lettieri $K$, Shubayev V, Jordanova A, Guergueltcheva V, Griffin PR, Burgess RW, Pfaff SL, Yang XL (2015) CMT2D neuropathy is linked to the neomorphic binding activity of glycyl-tRNA synthetase. Nature 526: 710-714

43. Kappé G, Franck E, Verschuure P, Boelens WC, Leunissen JAM, de Jong WW (2003) The human genome encodes 10 alpha-crystallin-related small heat shock proteins: HspB1-10. Cell Stress Chaperones 8: 53-61

44. Evgrafov OV, Mersiyanova I, Irobi J, Van Den Bosch L, Dierick I, Leung CL, Schagina O, Verpoorten N, Van Impe K, Fedotov V, Dadali E, Auer-Grumbach M, Windpassinger C, Wagner K, Mitrovic Z, Hilton-Jones D, Talbot K, Martin JJ, Vasserman N, Tverskaya S, Polyakov A, Liem RK, Gettemans J, Robberecht W, De Jonghe P, Timmerman V (2004) Mutant small heat-shock protein 27 causes axonal Charcot-Marie-Tooth disease and distal hereditary motor neuropathy. Nat Genet 36: 602-606

45. Irobi J, Van Impe K, Seeman P, Jordanova A, Dierick I, Verpoorten N, Michalik A, De Vriendt E, Jacobs A, Van Gerwen V, Vennekens K, Mazanec R, Tournev I, Hilton-Jones D, Talbot K, Kremensky I, Van Den Bosch L, Robberecht W, Van Vandekerckhove J, Van Broeckhoven C, Gettemans J, De Jonghe P, Timmerman V (2004) Hot-spot residue in small heat-shock protein 22 causes distal motor neuropathy. Nat Genet 36: 597-601

46. Kolb SJ, Snyder PJ, Poi EJ, Renard EA, Bartlett A, Gu, S, Sutton S, Arnold WD, Freimer ML, Lawson VH, Kissel JT, Prior TW (2010) Mutant small heat shock protein B3 causes motor neuropathy: utility of a candidate gene approach. Neurology 74: 502-506 
47. Jakob U, Gaestel M, Engel K, Buchner J (1993) Small heat shock proteins are molecular chaperones. J Biol Chem 268: 1517-1520

48. Garrido C, Paul C, Seigneuric R, Kampinga HH (2012) The small heat shock proteins family: the long forgotten chaperones. Int J Biochem Cell Biol 44: 1588-1592

49. Nefedova VV, Muranova LK, Sudnitsyna MV, Ryzhavskaya AS, Gusev NB (2015) Small heat shock proteins and distal hereditary neuropathies. Biochemistry (Mosc) 80: 1734-1747

50. Rzepnikowska W, Kochański A (2018) A role for the GDAP1 gene in the molecular pathogenesis of Charcot-Marie-Tooth disease. Acta Neurobiol Exp (Wars) 78: 1-13

51. Huber N, Guimaraes S, Schrader M, Suter U, Niemann A (2013) Charcot-Marie-Tooth disease-associated mutants of GDAP1 dissociate its roles in peroxisomal and mitochondrial fission. EMBO Rep 14: 545-552

52. Niemann A, Ruegg M, La Padula V, Schenone A, Suter U (2005) Ganglioside-induced differentiation associated protein 1 is a regulator of the mitochondrial network. J Cell Biol 170: 1067-1078

53. Pedrola L, Espert A, Wu X, Claramunt R, Shy ME, Palau F (2005) GDAP1, the protein causing Charcot-Marie-Tooth disease type 4A, is expressed in neurons and is associated with mitochondria. Hum Mol Genet 14: 1087-1094

54. Noack R, Frede S, Albrecht P, Henke N, Pfeiffer A, Knoll K, Dehmel T, Meyer Zu Hörste G, Stettner M, Kieseier BC, Summer H, Golz S, Kochanski A, Wiedau-Pazos M, Arnold S, Lewerenz J, Methner A (2012) Charcot-Marie-Tooth disease CMT4A: GDAP1 increases cellular glutathione and the mitochondrial membrane potential. Hum Mol Genet 21:150-162

55. Pla-Martín D, Rueda CB, Estela A, Sánchez-Piris M, González-Sánchez P, Traba J, de la Fuente S, Scorrano L, Renau-Piqueras J, Alvarez J, Satrústegui J, Palau F (2013) Silencing of the Charcot-Marie-Tooth disease-associated gene GDAP1 induces abnormal mitochondrial distribution and affects $\mathrm{Ca}^{2+}$ homeostasis by reducing store-operated $\mathrm{Ca} 2+$ entry. Neurobiol Dis 55: 140-151

56. Grohmann K, Schuelke M, Diers A, Hoffmann K, Lucke B, Adams C, Bertini E, Leonhardt-Horti H, Muntoni F, Ouvrier R, Pfeufer A, Rossi R, Van Maldergem L, Wilmshurst JM, Wienker TF, Sendtner M, Rudnik-Schöneborn S, Zerres K, Hübner C (2001) Mutations in the gene encoding immunoglobulin mu-binding protein 2 cause spinal muscular atrophy with respiratory distress type 1. Nat Genet 29: 75-77

57. Cottenie E, Kochanski A, Jordanova A, Bansagi B, Zimon M, Horga A, Jaunmuktane Z, Saveri P, Rasic VM, Baets J, Bartsakoulia M, Ploski R, Teterycz P, Nikolic M, Quinlivan R, Laura M, Sweeney MG, Taroni F, Lunn MP, Moroni I, Gonzalez M, Hanna MG, Bettencourt C, Chabrol E, Franke A, von Au K, Schilhabel M, Kabzińska D, Hausmanowa-Petrusewicz I, Brandner S, Lim SC, Song H, Choi BO, Horvath R, Chung KW, Zuchner S, Pareyson D, Harms M, Reilly MM, Houlden H (2014) Truncating and missense mutations in IGHMBP2 cause Charcot-Marie Tooth disease type 2. Am J Hum Genet 95: 590601

58. Liu L, Li X, Hu Z, Mao X, Zi X, Xia K, Tang B, Zhang R (2017) IGHMBP2-related clinical and genetic features in a cohort of Chinese Charcot-Marie-Tooth disease type 2 patients. Neuromuscul Disord 27: 193-199

59. Wagner JD, Huang L, Tetreault M, Majewski J, Boycott KM, Bulman DE, Care4Rare Canada Consortium, Dyment DA, McMillan HJ (2015) Autosomal recessive axonal polyneuropathy in a sibling pair due to a novel homozygous mutation in IGHMBP2. Neuromuscul Disord 25: 794-799

60. Guenther UP, Handoko L, Laggerbauer B, Jablonka S, Chari A, Alzheimer M, Ohmer J, Plöttner O, Gehring N, Sickmann A, von Au K, Schuelke M, Fischer U (2009) IGHMBP2 is a ribosome-associated helicase inactive in the neuromuscular disorder distal SMA type 1 (DSMA1). Hum Mol Genet 18: 1288-1300

61. Molnar GM, Crozat A, Kraeft SK, Dou QP, Chen LB, Pardee AB (1997) Association of the mammalian helicase MAH with the pre-mRNA splicing complex. Proc Natl Acad Sci USA 94: 7831-7836

62. de Planell-Saguer M, Schroeder DG, Rodicio MC, Cox GA, Mourelatos Z (2009) Biochemical and genetic evidence for a role of IGHMBP2 in the translational machinery. Hum Mol Genet 18: 2115-2126
63. Shababi M, Feng Z, Villalon E, Sibigtroth CM, Osman EY, Miller MR, Williams-Simon PA, Lombardi A, Sass TH, Atkinson AK, Garcia ML, Ko CP, Lorson CL (2016) Rescue of a mouse model of spinal muscular atrophy with respiratory distress Type 1 by AAV9-IGHMBP2 is dose dependent. Mol Ther 24: 855-866

64. Schenone A, Nobbio L, Mandich P, Bellone E, Abbruzzese M, Aymar F, Mancardi GL, Windebank AJ (1997) Underexpression of messenger RNA for peripheral myelin protein 22 in hereditary neuropathy with liability to pressure palsies. Neurology 48: 445-449

65. Suter U, Nave KA (1999) Transgenic mouse models of CMT1A and HNPP. Ann NY Acad Sci 883: 247-253

66. Passage E, Norreel JC, Noack-Fraissignes P, Sanguedolce V, Pizant J, Thirion X, Robaglia-Schlupp A, Pellissier JF, Fontes M (2004) Ascorbic acid treatment corrects the phenotype of a mouse model of Charcot-Marie-Tooth disease. Nat Med 10: 396-401

67. Sereda M, Meyer zu Horste G, Suter U, Uzma N, Nave KA (2003) Therapeutic administration of progesterone antagonist in a model of Charcot-Marie-Tooth disease (CMT-1A). Nat Med 9: 1533-1537

68. Robertson JF, Willsher PC, Winterbottom L, Blamey RW, and Thorpe S (1999) Onapristone, a progesterone receptor antagonist, as first-line therapy in primary breast cancer. Eur J Cancer 35: 214-218

69. Pareyson D, Reilly MM, Schenone A, Fabrizi GM, Cavallaro T, Santoro L, Vita G, Quattrone A, Padua L, Gemignani F, Visioli F, Laurà M, Radice D, Calabrese D, Hughes RA, Solari A; CMT-TRIAAL; CMT-TRAUK groups (2011) Ascorbic acid in Charcot-Marie-Tooth disease type 1A (CMT-TRIAAL and CMT-TRAUK): a double-blind randomized trial. Lancet Neurol 10: 320-328

70. Chumakov I, Milet A, Cholet N, Primas G, Boucard A, Pereira Y, Graudens E, Mandel J, Laffaire J, Foucquier J, Gilbert F, Bertrand V, Nave KA, Sereda MW, Vial E, Guedj M, Hajj R, Nabirotchkin S, Cohen D (2014) Polytherapy with a combination of three repurposed drugs (PXT3003) down-regulates Pmp22 over-expression and improves myelination, axonal and functional parameters in models of CMT1A neuropathy. Orphanet J Rare Dis 9: 201

71. Anon. Addex Announces (2013) Positive data with ADX71441 in a pre-clinical transgenic model of Charcot-Marie-Tooth 1A disease. Addex press release

72. Kalinichev M, Palea S, Haddouk H, Royer-Urios I, Guilloteau V, Lluel P, Schneider M, Saporito M, Poli S (2014) ADX71441, a novel, potent and selective positive allosteric modulator of the $\mathrm{GABA}_{\mathrm{B}}$ receptor, shows efficacy in rodent models of overactive bladder. Br J Pharmacol 171: 995-1006

73. Kalinichev M, Girard F, Haddouk H, Rouillier M, Riguet E, Royer-Urios I, Mutel V, Lütjens R, Poli S (2017) The drug candidate, ADX71441, is a novel, potent and selective positive allosteric modulator of the $\mathrm{GABA}_{\mathrm{B}}$ receptor with a potential for treatment of anxiety, pain and spasticity. Neuropharmacology 114: 34-47

74. Martini R (2014) Neuregulin-1 alleviates Charcot-Marie-Tooth disease in rats. Nat Med 20: 984-985

75. Monje PV (2015) To myelinate or not to myelinate: fine tuning cAMP signaling in Schwann cells to balance cell proliferation and differentiation. Neural Regen Res 10: 1936-1937

76. Fledrich R, Stassart RM, Klink A, Rasch LM, Prukop T, Haag L, Czesnik D, Kungl T, Abdelaal TA, Keric N, Stadelmann C, Brück W, Nave KA, Sereda MW (2014) Soluble neuregulin-1 modulates disease pathogenesis in rodent models of Charcot-Marie-Tooth disease 1A. Nat Med 20: 1055-1061

77. Klein D, Patzkó Á, Schreiber D, van Hauwermeiren A, Baier M, Groh J, West BL, Martini R (2015) Targeting the colony stimulating factor 1 receptor alleviates two forms of Charcot-Marie-Tooth disease in mice. Brain 138: 3193-3205

78. Bai Y, Patzko A, Shy ME (2013) Unfolded protein response, treatment and CMT1B. Rare Dis (Austin, Tex.) 1: e24049.

79. Das I, Krzyzosiak A, Schneider K, Wrabetz L, D’Antonio M, Barry N, Sigurdardottir A, Bertolotti A (2015) Preventing proteostasis diseases by selective inhibition of a phosphatase regulatory subunit. Science 348: 239-242 
80. Misko AL, Sasaki Y, Tuck E, Milbrandt J, Baloh RH (2012) Mitofusin 2 mutations disrupt axonal mitochondrial positioning and promote axon degeneration. J Neurosci 32: 4145-4155

81. Rocha AG, Franco A, Krezel AM, Rumsey JM, Alberti JM, Knight WC, Biris N, Zacharioudakis E, Janetka JW, Baloh RH, Kitsis RN, Mochly-Rosen D, Townsend RR, Gavathiotis E, Dorn GW (2018) MFN2 agonists reverse mitochondrial defects in preclinical models of Charcot-Marie-Tooth disease type 2A. Science 360: 336-341

82. d'Ydewalle C, Krishnan J, Chiheb DM, Van Damme P, Irobi J, Kozikowski AP, Vanden Berghe P, Timmerman V, Robberecht W, Van Den Bosch L (2011) HDAC6 inhibitors reverse axonal loss in a mouse model of mutant HSPB1-induced Charcot-Marie-Tooth disease Nat Med 17: 968-974

83. Shen S, Benoy V, Bergman JA, Kalin JH, Frojuello M, Vistoli G, Haeck W, Van Den Bosch L, Kozikowski AP (2016) Bicyclic-capped histone deacetylase 6 inhibitors with improved activity in a model of axonal Charcot-Marie-Tooth Disease. ACS Chem Neurosci 7: 240-258

84. Bilsland E, Bean DM, Devaney E, Oliver SG (2016) Yeast-based high-throughput screens to identify novel compounds active against Brugia malayi. PLoS Negl Trop Dis 10: e0004401

85. Estela A, Pla-Martín D, Sánchez-Piris M, Sesaki H, Palau F (2011) Charcot-Marie-Tooth-related gene GDAP1 complements cell cycle delay at G2/M phase in Saccharomyces cerevisiae fis1 gene-defective cells. J Biol Chem 286: 36777-36786

86. Kachroo AH, Laurent JM, Yellman CM, Meyer AG, Wilke CO, Marcotte EM (2015) Systematic humanization of yeast genes reveals conserved functions and genetic modularity. Science 348: 921-925

87. Sun S, Yang F, Tan G, Costanzo M, Oughtred R, Hirschman J, Theesfeld CL, Bansal P, Sahni N, Yi S, Yu A, Tyagi T, Tie C, Hill DE, Vidal M, Andrews BJ, Boone C, Dolinski K, Roth FP (2016) An extended set of yeast-based functional assays accurately identifies human disease mutations. Genome Res 26: 670-680

88. Zhang N, Osborn M, Gitsham P, Yen K, Miller JR, Oliver SG (2003) Using yeast to place human genes in functional categories. Gene 303: 121-129

89. Dunham MJ, Fowler DM (2013) Contemporary, yeast-based approaches to understanding human genetic variation. Curr Opin Genet Dev 23: 658-664

90. Lasserre JP, Dautant A, Aiyar RS, Kucharczyk R, Glatigny A, Tribouillard-Tanvier D, Rytka J, Blondel M, Skoczen N, Reynier P, Pitayu L, Rötig A, Delahodde A, Steinmetz LM, Dujardin G, Procaccio V, di Rago JP (2015) Yeast as a system for modeling mitochondrial disease mechanisms and discovering therapies. Dis Model Mech 8: 509-526

91. Oliveira AV, Vilaça R, Santos CN, Costa V, Menezes R (2017) Exploring the power of yeast to model aging and age-related neurodegenerative disorders. Biogerontology 18: 3-34

92. Rzepnikowska W, Flis K, Kaminska J, Grynberg M, Urbanek A, Ayscough KR, Zoladek T (2017) Amino acid substitution equivalent to human chorea-acanthocytosis I2771R in yeast Vps13 protein affects its binding to phosphatidylinositol 3-phosphate. Hum Mol Genet 26: $1497-1510$

93. Abbott JA, Meyer-Schuman R, Lupo V, Feely S, Mademan I, Oprescu SN, Griffin LB, Alberti MA, Casasnovas C, Aharoni S, Basel-Vanagaite L, Züchner S, De Jonghe P, Baets J, Shy ME, Espinós C, Demeler B, Antonellis A, Francklyn C (2018) Substrate interaction defects in histidyl-tRNA synthetase linked to dominant axonal peripheral neuropathy. Hum Mutat 39: 415-432

94. Antonellis A, Lee-Lin SQ, Wasterlain A, Leo P, Quezado M, Goldfarb LG, Myung K, Burgess S, Fischbeck KH, Green ED (2006) Functional analyses of glycyl-tRNA synthetase mutations suggest a key role for tRNA-charging enzymes in peripheral axons. J Neurosci 26: 1039710406

95. Motley WW, Griffin LB, Mademan I, Baets J, De Vriendt E, De Jonghe $\mathrm{P}$, Antonellis A, Jordanova A, Scherer SS (2015) A novel AARS mutation in a family with dominant myeloneuropathy. Neurology 84: 2040-2047

96. Griffin LB, Sakaguchi R, Mcguigan D, Gonzalez MA, Searby C, Zuchner S, Hou YM Antonellis A (2014) Impaired function is a common feature of neuropathy-associated glycyl-tRNA synthetase mutations. Hum Mutat 35: 1363-1371

97. McLaughlin HM, Sakaguchi R, Giblin W, NISC Comparative Sequencing Program, Wilson TE, Biesecker L, Lupski JR, Talbot K, Vance JM, Züchner S, Lee YC, Kennerson M, Hou YM, Nicholson G, Antonellis A (2012) A recurrent loss-of-function alanyl-tRNA synthetase (AARS) mutation in patients with charcot-marie-tooth disease type 2N (CMT2N). Hum Mutat 33: 244-253

98. Wallen RC, Antonellis A (2013) To charge or not to charge: mechanistic insights into neuropathy-associated tRNA synthetase mutations. Curr Opin Genet Dev 23: 302-309

99. Amiott EA, Cohen MM, Saint-Georges Y, Weissman AM, Shaw JM (2009) A mutation associated with CMT2A neuropathy causes defects in Fzo1 GTP hydrolysis, ubiquitylation, and protein turnover. Mol Biol Cell 20: 5026-5035

100. Chow CY, Zhang Y, Dowling JJ, Jin N, Adamska M, Shiga K, Szigeti K, Shy ME, Li J, Zhang X, Lupski JR, Weisman LS, Meisler MH (2007) Mutation of FIG4 causes neurodegeneration in the pale tremor mouse and patients with CMT4J. Nature 448: 68-72

101. Moustaq L, Smaczynska-de Rooij II, Palmer SE, Marklew CJ, Ayscough KR (2016) Insights into dynamin-associated disorders through analysis of equivalent mutations in the yeast dynamin Vps1. Microb cell (Graz, Austria) 3: 147-158

102. Lenk GM, Ferguson CJ, Chow CY, Jin N, Jones JM, Grant AE, Zolov SN, Winters JJ, Giger RJ, Dowling JJ, Weisman LS, Meisler MH (2011) Pathogenic mechanism of the FIG4 mutation responsible for Charcot-Marie-Tooth disease CMT4J. PLoS Gene. 7: e1002104

103. Couplan E, Aiyar RS, Kucharczyk R, Kabala A, Ezkurdia N, Gagneur J, St Onge RP, Salin B, Soubigou F, Le Cann M, Steinmetz LM, di Rago JP, Blondel M (2011) A yeast-based assay identifies drugs active against human mitochondrial disorders. Proc Natl Acad Sci USA 108: 11989-11994

104.Jo M, Chung AY, Yachie N, Seo M, Jeon H, Nam Y, Seo Y, Kim E, Zhong Q, Vidal M, Park HC, Roth FP, Suk K (2017) Yeast genetic interaction screen of human genes associated with amyotrophic lateral sclerosis: identification of MAP2K5 kinase as a potential drug target. Genome Res 27: 1487-1500

105.Seguin A, Monnier V, Palandri A, Bihel F, Rera M, Schmitt M, Camadro J, Tricoire H, Lesuisse E (2015) A Yeast/Drosophila screen to identify new compounds overcoming frataxin deficiency. Oxid Med Cell Longev 2015: 565140

106. Tardiff DF, Jui NT, Khurana V, Tambe MA, Thompson ML, Chung CY, Kamadurai HB, Kim HT, Lancaster AK, Caldwell KA, Caldwell GA, Rochet JC, Buchwald SL, Lindquist S (2013) Yeast reveal a "druggable" Rsp5/Nedd4 network that ameliorates a-synuclein toxicity in neurons. Science 342: 979-983

107.Shy ME (2006) Therapeutic strategies for the inherited neuropathies. Neuromolecular Med 8: 255-278

108.Glorioso JC, Mata M, Fink DJ (2003) Therapeutic gene transfer to the nervous system using viral vectors. J Neurovirol 9: 165-172

109.Scherer SS, Xu YT, Messing A, Willecke K, Fischbeck KH, Jeng LJ (2005) Transgenic expression of human connexin32 in myelinating Schwann cells prevents demyelination in connexin32-null mice. J Neurosci 25: 1550-1559

110.Sargiannidou I, Kagiava A, Bashiardes S, Richter J, Christodoulou C, Scherer SS, Kleopa KA (2015) Intraneural GJB1 gene delivery improves nerve pathology in a model of X-linked Charcot-Marie-Tooth disease. Ann Neurol 78: 303-316

111.Kagiava A, Sargiannidou I, Theophilidis G, Karaiskos C, Richter J, Bashiardes S, Schiza N, Nearchou M, Christodoulou C, Scherer SS, Kleopa KA (2016) Intrathecal gene therapy rescues a model of demyelinating peripheral neuropathy. Proc Natl Acad Sci USA 113: E2421E2429

112. Nizzardo M, Simone C, Rizzo F, Salani S, Dametti S, Rinchetti P, Del Bo R, Foust K, Kaspar BK, Bresolin N, Comi GP, Corti S (2015) Gene therapy rescues disease phenotype in a spinal muscular atrophy with respiratory distress type 1 (SMARD1) mouse model. Sci Adv 1: e1500078 
113.Sahenk Z, Nagaraja HN, McCracken BS, King WM, Freimer ML, Cedarbaum JM, Mendell JR (2005) NT-3 promotes nerve regeneration and sensory improvement in CMT1A mouse models and in patients. Neurology 65: 681-689

114.Sahenk Z, Galloway G, Clark KR, Malik V, Rodino-Klapac LR, Kaspar BK, Chen L, Braganza C, Montgomery C, Mendell JR (2014) AAV1. NT-3 gene therapy for charcot-marie-tooth neuropathy. Mol Ther 22: 511-521

115. Yalvac ME, Arnold WD, Braganza C, Chen L, Mendell JR, Sahenk Z (2016) AAV1.NT-3 gene therapy attenuates spontaneous autoimmune peripheral polyneuropathy. Gene Ther 23: 95-102

116. Wolfe D, Mata M, Fink DJ (2012) Targeted drug delivery to the peripheral nervous system using gene therapy. Neurosci Lett 527: 85-89

117. Lopes CD, Oliveira H, Estevão I, Pires LR, Pêgo AP (2016) In vivo targeted gene delivery to peripheral neurons mediated by neurotropic poly(ethylene imine)-based nanoparticles. Int J Nanomedicine 11: 2675-2683. Erratum in: Int J Nanomedicine (2017) 12: 5631
118. Hai M, Bidichandani SI, Hogan ME, Patel PI. Competitive binding of triplex-forming oligonucleotides in the two alternate promoters of the PMP22 gene (2001) Antisense Nucleic Acid Drug Dev 11: 233-246

119.Zhao HT, Damle S, Ikeda-Lee K, Kuntz S, Li J, Mohan A, Kim A, Hung G, Scheideler MA, Scherer SS, Svaren J, Swayze EE, Kordasiewicz HB (2018) PMP22 antisense oligonucleotides reverse Charcot-Marie-Tooth disease type 1A features in rodent models. J Clin Invest 128: 359-368

120.Lee JS, Chang EH, Koo OJ, Jwa DH, Mo WM, Kwak G, Moon HW, Park HT, Hong YB, Choi BO (2017) Pmp22 mutant allele-specific siRNA alleviates demyelinating neuropathic phenotype in vivo. Neurobiol Dis 100: 99-107

121. Tipanee J, Chai YC, Vanden Driessche T, Chuah MK (2017) Preclinical and clinical advances in transposon-based gene therapy. Biosci Rep 37: BSR20160614

\title{
Therapeutic perspective in hereditary polyneuropathies
}

\section{Dagmara Kabzińska, Weronika Rzepnikowska, Katarzyna Binięda, Artur Kiepura, Andrzej Kochański}

Mossakowski Medical Research Centre PAS, 5 Pawinskiego St., 02-106 Warsaw, Poland

凶e-mail: akochanski@imdik.pan.pl

Key words: CMT disease, molecular pathogenesis, experimental therapy

\begin{abstract}
Hereditary motor and sensory neuropathies (HMSN) also called as Charcot-Marie-Tooth disorders (CMT) are extremely heterogeneous group of disorders of peripheral nervous system. Over 80 genes have been reported in different types of CMT. In all CMT affected patients the main symptoms are slowly progressive wasting of the distal muscles of the lower and upper limbs. To date no efficient therapeutic approach based upon molecular pathology of CMT has been proposed. This review presents the current state of knowledge concerning clinical, molecular pathogenesis and experimental therapy aspects in CMT disorders. Additionally the possibilities resulting from the use of the yeast model to the identification of new therapeutic substances as well as of neurotoxins are also discussed.
\end{abstract}

